\title{
Diversity of fish species in several sites along the Brantas river East Java Indonesia
}

\author{
Nuril Ahmad ${ }^{1,2}$, Luchman Hakim², Catur Retnaningdyah², Bagyo Yanuwiadi² \\ ${ }^{1}$ Department of Biology, Faculty of Mathematics and Natural Sciences, Brawijaya University Malang \\ ${ }^{2}$ Department of Agriculture Technology, Faculty of Technology, Majapahit Islamic University, Jl. \\ Raya Jabon KM 0,7 Mojokerto. 61364. \\ Indonesia
}

Received: February 6, 2021. Revised: August 1, 2021. Accepted: August 27, 2021. Published: August 30, 2021.

\begin{abstract}
The purpose of this study is to describe the presence of species diversity and composition in Bratas River. Fish sampling was conducted in dry and rainy seasons in five locations, namely Batu City, Blitar City, Tulungagung regency, Jombang Regency, and Mojokerto Regency, East Java. This study collected 295 individual fishes belonging to 12 species. The 162 individuals were obtained in the dry season, while 133 individuals were captured in rainy season. The most dominant species was mujahir (Oreochromis mosambica) followed by keting (Mystus paniceps) and kutuk (Channa striata). The fish abundance significantly varied among study sites, while that of species richness and diversity did not differ significantly. Fish diversity in high elevation was the lowest, while that in relatively middle elevation was the highest. Compared to the previous report, fish species diversity in Brantas was decreasing, some species were not found. Three species were considered as exotic include Oreochromis mosambica, Clarias batracus, Oreochromis niloticus.
\end{abstract}

Keywords- Brantas River, fish species, diversity, evaluate the presence

\section{INTRODUCTION}

$\mathrm{R}^{\mathrm{s}}$ IVERINE fishes are a taxonomically threatened group because of their high sensitivity to quantitative and qualitative changes in river ecosystems [1]. Rapid industrialization, intensive agriculture, overexploitation, and habitat changes along are crucial threats to the sustainability of fish community in lots of rivers [2]. Invasive species and habitat degradation are among the main threat to diversity loss [3]. Issues regarding the impact of the introduction of exotic species have been discussed globally, because the cases for aquaculture, fisheries and the pet trade has increased rapidly
[4]. Cultivation of aquaculture, mosquito control e.g. malaria, sport fishing, ornamental purposes, research activities, demonstrations at national fairs and accidental introductions are the main reasons for this introduction. Moreover, these trade regulations are rather lax and lack of general data on the ecological impacts of non-native fish species, despite the fact that one-third of the world's worst aquatic invasive species are aquarium or ornamental species [5]. In general, whether the impact of these introductions is positive or negative depends on the context [6], [7] and has been the source of much debate [8]-[10]. In general, the negative impact is decrease in the diversity of local species, while the positive effect is contributed from the economic and trade sectors. Therefore, research on the impacts of non-native fish is important for developing solutions to conservation problems [11], [12]. One of the important studies that need attention is fish diversity.

Slow and inadequate conservation measures to reduce the effects of fish stress have led to many species decline [13]. Conserving biodiversity in an area requires an appropriate management strategy. Species diversity data is very necessary to support the success of conservation strategies. Several studies on fish biodiversity have been carried out around the world [14]-[18] Most of those studies are concern about the species decline and emphasized conservation activities. A study in Klawing River, Central Java found 18 species, four of them are exotic species [19](Suryaningsih et al 2018), research in three tributary streams in Serayu Basin Central Java found 14 species, three of them are exotic species [20](Suryaningsih et al 2020), research in Aceh found 114 fish species, 9 of which are exotic species [21](Muchlisin and Azizah, 2009). A study in Cibareno rivers, Mountain Halimun National Park found 29 species, three of which are exotic [22](Rachmatika et al, 2002). Oreochromis mosambicus, Cyprinus carpio, Oreochromis niloticus, Poecilia reticulata are among the most common exotic species reported in those studies. The presence of exotic species is usually associated with developing aquaculture and the pet trade. 
One of the developing fisheries and the pet trade locations is in East Java. Brantas Rivers is one of the important river ecosystems in this region. This river supports millions of people who live along with the river's ecosystem. Brantas provides water resources for numerous human activities along the area which was passed by the river ecosystem, including agriculture, fisheries, industry, and tourism [19]. Hence, the area along Brantas River has developed very quick and contributed significantly to ecosystem quality degradation.

Brantas is one of the interesting river's ecosystems which was estimated home to numerous rivers ecosystem. Fishes are one of the interesting targets for biodiversity surveys. The first study on fish diversity in Brantas Rivers found 87 fish species. To generate fish data under the rapid development of houses and settlements along Brantas River, [20], enlarge the survey area from upstream to the estuary, and found 59 species of freshwater fish.

The rapid development of the area alongside Brantas River seems to contribute to the decrease of freshwater fishes in Brantas Rivers. Over exploitation, intensive agriculture, and habitat changes along Brantas Rivers seems responsible for the decrease of fishes [20], [21]. Environmental degradation was reported to contribute to fish habitat destruction [22]. Diversity and composition surveys of fish can provide important information regarding two things, first is the status of threats to fish diversity by river quality and second is the existing condition of fish composition that is still able to survive as a resource that can be utilized by local communities. A checklist of recent biodiversity status is often important to determine the changes of species extinction in a particular ecosystem. A checklist is one of the crucial instruments in biodiversity management. The purpose of this study is to describe the presence of species diversity and composition in Brantas River.

\section{MATERIALS AND METHODS}

This study was carried out in Brantas River, East Java, Indonesia in 2019. Sampling was conducted in dry and rainy seasons, in five study sites. Te study sites were selected purposively to represent different elevation, in Batu City, Blitar City, Tulungagung Regency, Jombang Regency and Mojokerto Regency. Those sites represented important City in which the development has grown rapidly in recent years. In East Jave rainy season occurs from October to February, while the dry occurs from April to September. In each location, samplings were conducted at fur points. In Batu, the samplings were done in Sidomulyo (Sdm), Kungkuk (KK), Coban Talun, (CT) and Sumber Brantas (SB). In Blitar, samplings were performed in Bendungan Wlingi (BW), Sukojayan (Skj), Bendungan serut (BS), and Rejowinagun (Rej). In Tulungagung, it was conducted in Lembu peteng (Lp), Bandung (Bdg), Ngujang (Ngj), ND Bendosari (Bd). In Jombang it was include Jembatan perak (JP), Plandaan (Pld), Ploso (Pls), and Tapen (Tp). In Mojokerto it was included in
Mbetro kemlagi (Mb), Gombongan (Gbg), Kemantren gedek (KG) and Lengkong (Lk) (Figure 1). Fish samplings were done twice daily, in the morning (7:00 to 10:00) and afternoon (14:00 to 17:00), each using a duration of 3 hours. Samplings were carried out by placing a gill net measuring $2-4 \mathrm{~cm}$ at a predetermined location. All samples were transferred to the Laboratory of Animal Diversity Universitas Brawijaya for species identification. The identification was done base on several literatures [23]-[25]. The data were analyzed using the Shannon Wiener index (diversity analysis), and the BrayCurtis index. The differences of mean abundance between locations and seasons were tested by one-way analysis of variance. Statistical tests were performed using Excel and SPSS ${ }^{\circledR}$ version 20 (SPSS Inc. Chicago, IL, USA).

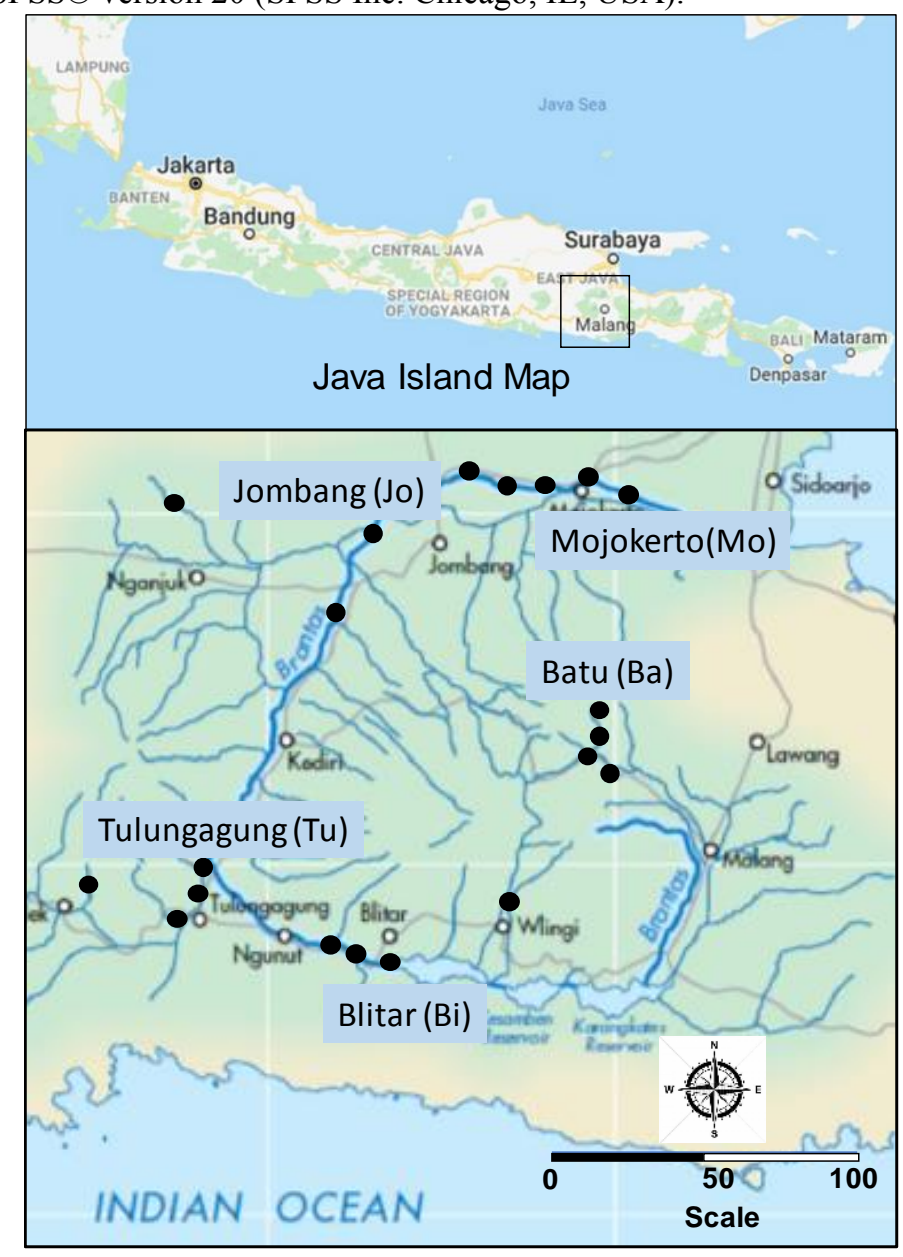

Fig. 1 Study sites in Batu, Blitar, Tuluingagung, Jombang and Mojkerto, East Java, Indonesia

\section{RESULTS AND DISCUSSION}

\section{A. Result}

This study collected 295 individual fishes belonging to 12 species. The 162 individuals were obtained in the dry season, while 133 individuals were captured in the rainy season. The most dominant species was mujahir (Oreochampus mosambicca) followed by keting (Mystus paniceps) and kutuk (Channa sriata). Eight species were considered vulnerable, 
these consisted of Mystus paniceps, Barbodes balleroides, Pseudoleis micronemus, Barbodes gonionatus, Trichogaster tricepterus, Pangasius djambal, Hemibragus nemurus, and Poecilla reticulata (Table 1). The mean of fish abundance was highest in Blitar (9.75 individuals both in dry and rainy season), while the lowest was found in Batu (4.25 individuals in the dry season and 2.5 individuals in rainy season). The fish abundance varied significantly among study sites $(\mathrm{P}<0.05)$ (Figure 2). The highest species richness was found in Blitar (11 to 12 species) while the lowest was found in Batu (5 species) (Figure 3). Of the total species found, three species were classified as exotic, namely Oreochromis mosambicus, Clarias batracus, Oreochromis niloticus.

Table 1 . Fish abundance collected from study sites in the dry and rainy season

\begin{tabular}{|c|c|c|c|c|c|c|c|c|c|c|c|c|c|}
\hline \multirow[t]{2}{*}{ Species name } & \multirow[t]{2}{*}{ Status } & \multirow[t]{2}{*}{ Local name } & \multicolumn{5}{|c|}{ Dry season } & \multicolumn{5}{|c|}{ Rainy season } & \multirow[b]{2}{*}{ Total } \\
\hline & & & $\mathrm{Ba} 1$ & Bil & Tu1 & Jo1 & Mo1 & $\mathrm{Ba} 2$ & $\mathrm{Bi} 2$ & $\mathrm{Tu} 2$ & $\mathrm{Jo} 2$ & Mo2 & \\
\hline Oreochromis & $\mathrm{LC}$ & Mujair & & & & & & & & & & & \\
\hline Mystus paniceps & VU & Keting & 0 & 4 & 7 & 7 & 5 & 0 & 4 & 3 & 2 & 3 & 35 \\
\hline Channa striata & $\mathrm{LC}$ & Kuthuk* & 0 & 4 & 3 & 4 & 3 & 0 & 4 & 4 & 4 & 2 & 28 \\
\hline Barbodes gonionatus & VU & Bader Putih & 0 & 5 & 4 & 2 & 1 & 0 & 4 & 3 & 1 & 4 & 24 \\
\hline Trichogaster tricepterus & VU & Sepat* & 3 & 3 & 1 & 1 & 0 & 5 & 4 & 4 & 2 & 0 & 23 \\
\hline Pangasius djambal & VU & Jambal & 0 & 2 & 2 & 2 & 3 & 0 & 3 & 3 & 4 & 2 & 21 \\
\hline Clarias batrachus & $\mathrm{LC}$ & Lele & 2 & 2 & 6 & 0 & 1 & 1 & 2 & 5 & 0 & 0 & 19 \\
\hline Oreochromis niloticus & $\mathrm{LC}$ & Nila & 1 & 0 & 0 & 1 & 1 & 0 & 2 & 1 & 0 & 0 & 6 \\
\hline & & & 17 & 39 & 40 & 33 & 33 & 10 & 39 & 33 & 28 & 23 & 295 \\
\hline
\end{tabular}

Note: *Conservation status was determined based on IUCN red list data (IUCN, 2017).

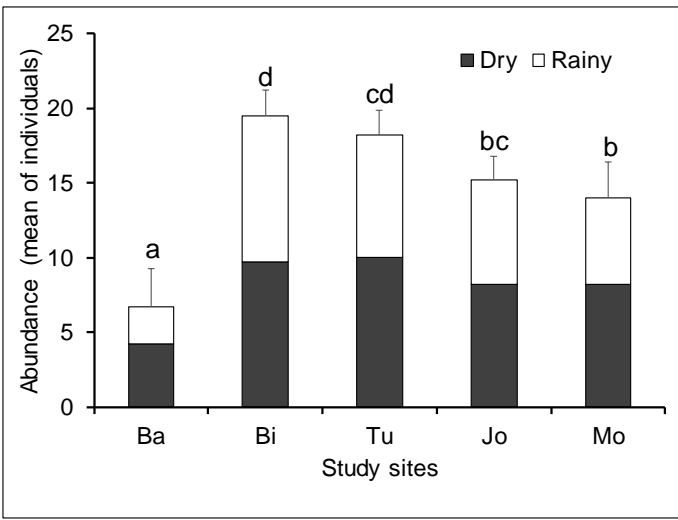

Fig. 2 the mean of fish abundance ( \pm Stdev) among the study sites,

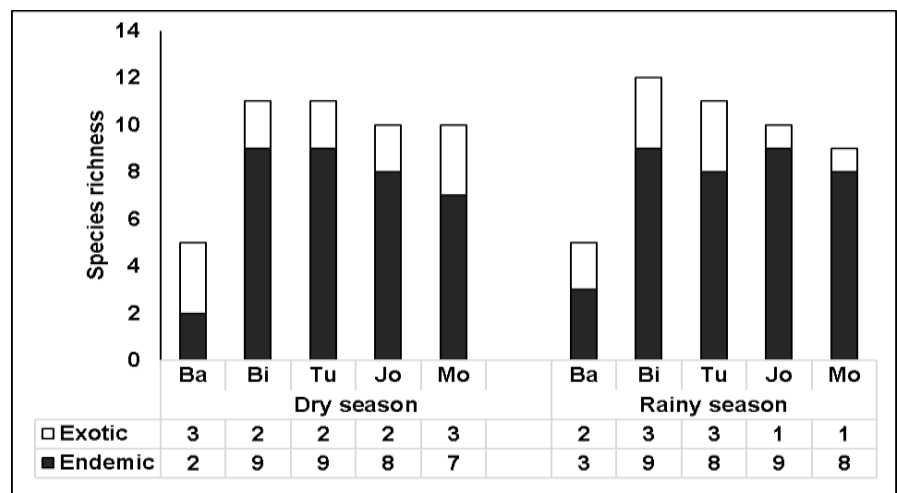

Fig. 3 species richness of fishes in the Brantas River E-ISSN: 1998-4510 note; different alphabet above the error bar indicated the significant different among the means

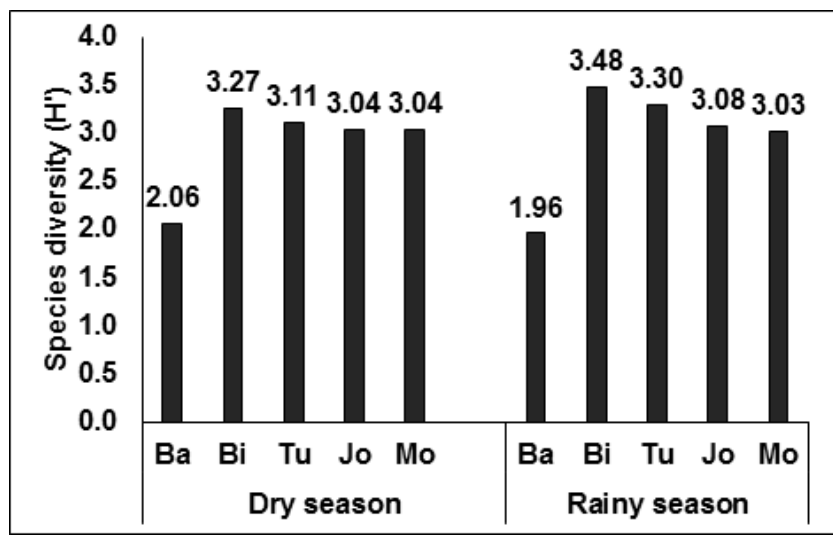

Fig. 4 species diversity of fishes in the Brantas River

Fish species richness ranged from 5 to 12 among the study sites. The level of fish species diversity varied along with the study sites. The highest diversity was found in Blitar both during the dry season (3.27) and the rainy season (3.48); while the lowest was found in Batu in both the dry (2.06) and rainy (1.96) seasons. Statistical analysis showed that season does not have a significant effect on fish diversity (Figure 4).

Cluster analysis showed that fish compositions were grouped according regions (adjacent areas). The first group 
consisted of fish compositions from Blitar and Tulungagung. The second group consisted of those from Jombang and Mojokerto dry season. The first and second groups combined with that from Mojokerto rainy season to form the bigger cluster. The last group consisted of those from Blitar (Figure 5). This shows that there is an effect of elevation on the similarity of the composition of the fish caught.

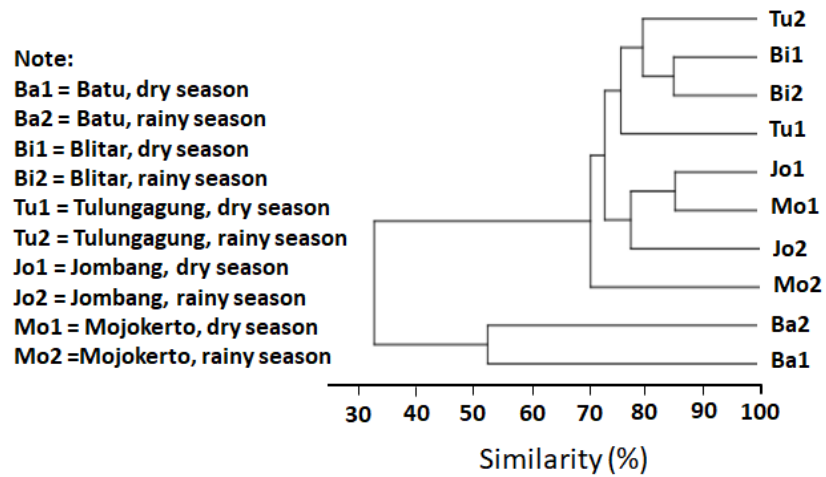

Fig. 5 the similarity of fish composition among study sites and between
Compare to previous years, this study collected same species richness as that in 2017 , but only four of those exactly same species. Study in 1998 showed the highest species richness (53 species). Study in 2017 collected the species records Trichopsis vittata, Xiphophorus helleri and Aequidens pulcher compare to those in 1998 (Table 2).

Table 2. Composition of Fish Species that have been Reported and Current Findings in the Brantas River

\begin{tabular}{|c|c|c|c|c|c|c|c|}
\hline \multirow{2}{*}{ No } & \multicolumn{2}{|r|}{ Species } & \multirow[t]{2}{*}{ Family } & \multirow{2}{*}{$\begin{array}{c}\begin{array}{c}\text { Current } \\
\text { study }\end{array} \\
2019\end{array}$} & \multicolumn{3}{|c|}{ Previous studies } \\
\hline & Local name & Scientific name & & & 2017 & 2008 & 1998 \\
\hline 1 & Berot & Mastechembelus unicolor & Mastacembelidae & & & * & * \\
\hline 2 & Bader merah & Barbodes balleroides & Cyprinidae & * & & * & * \\
\hline 3 & Bader putih & Barbodes gonionatus & Cyprinidae & * & & * & * \\
\hline 4 & Belut & Monopterus albus & Flutidae & & & & * \\
\hline 5 & Kuniran & Mystacoleocus marginatus & muliidae & & & & * \\
\hline 6 & Bethik & Anabas testudineus & Anabantidae & & * & & * \\
\hline 7 & Betutu & Axyeleotris marmorata & Eleotridae & & & & * \\
\hline 8 & Cucut & Dermogenys pussila & Hemiramphidae & & * & & * \\
\hline 9 & Wader bintik dua & Puntius binotatus & Cyprinidae & & * & & * \\
\hline 10 & Gurame & Osphpronemus goramy & Osphronemidae & & & & * \\
\hline 11 & Jambal & Pangasius djambal & Pangasiidae & * & & & * \\
\hline 12 & Jendil & Pseudoleis micronemиs & Pangasiidae & * & & & * \\
\hline 13 & Keting & Mystus paniceps & Bagridae & * & & & * \\
\hline 14 & Kutuk & Channa striata & Channidae & * & * & * & * \\
\hline 15 & Muraganthing & Barbonimous altus & Cyprinidae & & & $*$ & * \\
\hline 16 & Nila & Oreochampis niloticus & Tilpadae & $*$ & & $*$ & * \\
\hline 17 & Papar Merah & Notpterus notopterus & Notopteridae & & & $*$ & * \\
\hline 18 & Papar Biru & Nopterus chilata & Notopteridae & & & & * \\
\hline 19 & Palung & Hamphala macrolepidota & Cypriniidae & & & & * \\
\hline 20 & Rengkik & Hemibragus neтurus & Bagridae & * & & & * \\
\hline 21 & Sili & Macrognatus aculeatus & Mastacembelidae & & & & * \\
\hline 22 & Sepat & Trichogaster tricepterus & Osphronemidae & * & & & * \\
\hline 23 & Seren & Anematicthys apogon & Cyprinidae & & & & $*$ \\
\hline 24 & Suckermouth & Pterygoplichtys Perdalis & Loricariidae & & $*$ & & $*$ \\
\hline 25 & Ulo & Laides longibarbis & Schilbeidae & & & & * \\
\hline 26 & Wader & Cyclocheiltys $s p$ & Cyprinidae & & & & * \\
\hline 27 & Lokas/W. gunung & Labiobarbus leptocheilus & Cyprinidae & & & & * \\
\hline 28 & Jogoripo & Achrochordonithyus rugosus & Akysidae & & & * & * \\
\hline 29 & Pengkih & Ambasis nalua & Anabantidae & & & * & * \\
\hline
\end{tabular}




$\begin{array}{lll}30 & \text { Kepala Timah } & \text { Aplocheilus panchax } \\ 31 & \text { Bandeng } & \text { Chanos cahnos } \\ 32 & \text { Lele Lokal } & \text { Clarias batracus } \\ 33 & \text { Lele Dumbo } & \text { Clarias gariepiens } \\ 34 & \text { Tombro } & \text { Cyprinus carpio } \\ 35 & \text { Tapel Watu } & \text { Glyptorax platypogan } \\ 36 & \text { Keprek } & \text { Helostoma lemmenicki } \\ 37 & \text { Sogoprono } & \text { Ichtyocampus carce } \\ 38 & \text { Areng-areng } & \text { Labeo chrsyophekadion } \\ 39 & \text { Sengkaring } & \text { Labeobarbus siamensis } \\ 40 & \text { Baung } & \text { Mystus gulio } \\ 41 & \text { Lenger } & \text { Macrones nemurus } \\ 42 & \text { Bekel } & \text { Mystus nigriceps } \\ 43 & \text { Uceng } & \text { Nemachilus fasciatus } \\ 44 & \text { Kotes } & \text { Ophiochephakus gachua } \\ 45 & \text { Bekes } & \text { Ophiochepalus melanopterus } \\ 46 & \text { Nilem } & \text { Osteochlus haseltii } \\ 47 & \text { Mengkreng } & \text { Pangasius nasutus } \\ 48 & \text { Gatul } & \text { Poecilla reticulata } \\ 49 & \text { Wader kuning } & \text { Rasboralateristriata } \\ 50 & \text { Lawak } & \text { Puntius bromoides } \\ 51 & \text { Wader pari } & \text { Rasbhora ayrotaenia } \\ 52 & \text { Mujair } & \text { Oreochampus mosambicca } \\ 53 & \text { Croaking gourami } & \text { Trichopsis vittata } \\ 54 & \text { Cingir putri } & \text { Xiphophorus helleri } \\ 55 & \text { Garingan } & \text { Tor tambroides } \\ 56 & \text { Golosom } & \text { Aequidens pulcher } \\ 57 & \text { Kebogerang } & \text { Mystus nigriceps } \\ & & \\ & \text { Total } & \end{array}$

Source: several studies [20], [22], [26]

\section{B. Discussion}

Our study collected lowest species number in highest elevation site (Batu), while highest species richness occurred in Blitar during rainy season. The fish diversity and compositions from Blitar and Tulungagung have closer similarity that those from other sites. These results are consistent with studies conducted in Columbia (South America) and Europe. Study in Columbia showed that the highest species richness was found at lower elevations $\leq 500$ and $1000 \mathrm{~m}$ a.s.l.; species richness decreased with increasing elevation. However, diversity patterns of common and dominant species decreased with increasing elevation to 2000 $\mathrm{m}$ a.s.l., but there was a marked increase at $1250 \mathrm{~m}$ a.s.1 [27]. In European studies it was reported that species richness and diversity decreased in the upper part of the gradient; and fish abundance showed a unimodal response to elevation; the highest numbers were found at elevations between 250 and $500 \mathrm{~m}[28]$.

This study found 12 species of fish in all sampling sites in Brantas River (Table 1). Compared to Risjani et al., (1998) study (Table 2), this finding showed a lower species richness, indicated a tendency of number of species decreasing. Studies during last ten years showed the number of fish species in this river ranged from $9-12$ [22], [26]. Anthropogenic effects related to habitat change, the introduction of exotic species as well as river blockages for irrigation, channeling, sand

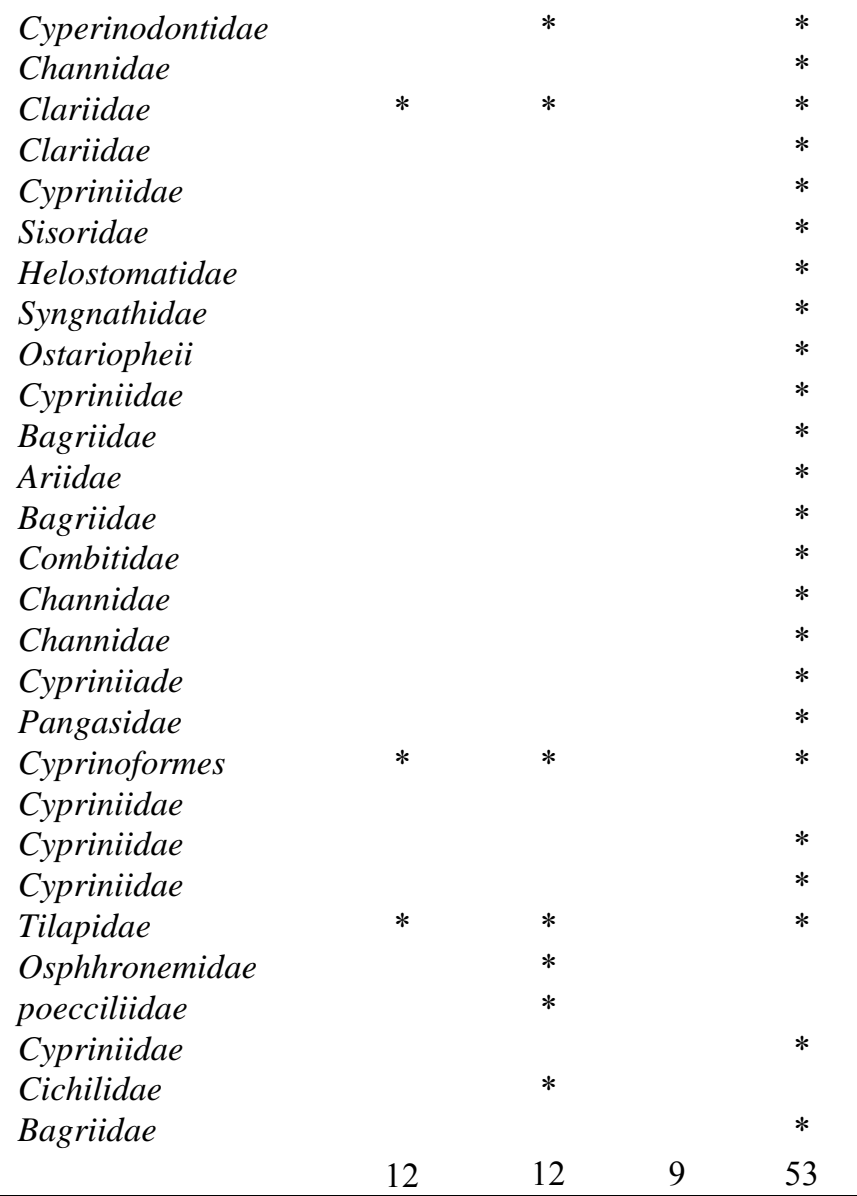

dredging, silting river bodies, industrial area in down streaming sites and the development of settlements around the Brantas River were among the important threats. These threats lead to disruptions to the fish food base and habitat. East Java Province is one of the provinces with a very high level of physical development, for example the construction of highways, bridges, housing and other facilities (sumarjoko). In addition, agricultural and gardening activities are also high. In some areas there are also various industries. With numerous of activities, pollutants and sediments enter river bodies and become the main source of air pollution.

The fish population in East Java is dominated by Cyprinidae and Tilapiidae composed of approximately $50 \%$ of the species. The populations of these fish species have changed from year to year both in number of individuals and species. The presence of non-native species such as Oreochromis mosambicus, Clarias batracus, Oreochromis niloticus has been reported since 1998 in Brantas [20], [22], [26]. Cases of introduction of these species have also been reported in various studies abroad. Cyprinus carpio, Carassius auratus, Oreochromis mosambicus, Oreochromis niloticus were among the invasive species which received much concern [29]-[33]. These exotic fish species are easily found in Brantas and other rivers in Indonesia. This situation often associates with the extensive development of aquaculture aim to improve the economy of the local community. Extensive development of aquaculture has ascociated with the a 
significant contributor to global fish production, destined for both international and domestic markets. The same thing is also experienced by Malaysia, income, expenses, saving, ownership, housing, and religion significantly influenced the quality of life of fishermen (Ghani et al 2019).

Cultivated fish that come out of aquaculture and enter river waters become a main threat to local fish diversity. This affects the abundance and distribution patterns of native freshwater fauna [34] and reduces species diversity [35]-[37], resulting in severe negative effects on the structure and function of freshwater ecosystems [8], [38]. The environmental and biological changes that arise from this introduction are very detrimental to the local species that inhabit the Brantas river because the existence of a high species richness and endemism.

The ability of exotic fish to survive and displace local species due to their high level of tolerance in their environment and high reproduction rate [39], [40]. Environmental characteristics that support high fish diversity (e.g. availability of resources and warm water temperatures) are positively related to abundance, for example in the case of round goby (Neogobius melanostomus) introduction [41]. In general, the invasive species reduces the resources for the native species, and the effect is adjusted according to how the invader is incorporated into the community. Higher native diversity reduces the impact of invaders, emphasizing the need to consider biodiversity when predicting the impacts of invasive species [30]. The interrelationship between population dynamics and species invasion and public awareness can be an effective management strategy to minimize the impact of bio-invasion [29]. The mechanisms may occur by biotic interactions, such as competition or predation that affect population growth [42]. Several previous studies have questioned whether alien species are a direct driver of the loss of native species through biotic interactions, or a decline in passengers caused by environmental changes (e.g., habitat degradation and pollution)[3]. Habitat changes can alter the availability of resources such as nutrients, food, and space, thus acting as "natural selection" that favors for non-native species survival and disadvantage local species. Thus, habitat change may increase invasion success by facilitating increased local abundance and the spread of regional invaders [3].

Another factor that affects fish diversity and abundance is water quality. The deterioration of water quality has been recognized as a potential challenge which directly impacts the aquatic organisms leading to decline in diversity. Given the increasing pressure on aquatic systems, documenting the available richness and establishing accurate estimates of the magnitude of biodiversity loss resulting from common human disturbances, such as land-use change and habitat loss, species invasions, and climate change is of particular importance (Murphy and Romanuk, 2014). Physico-chemical characteristics are important determinants reflecting the condition of freshwater fish assemblages. It has been established that habitat variables such as water temperature, velocity, substrate, conductivity, depth and width, altitude and distance from the source influence river fish composition (Li et al., 2012). The richness and abundance of fishes were correlated with land-use type, canopy cover, $\mathrm{pH}$ and turbidity. Diversion of water, discharge of domestic sewage and agricultural runoff were prominent among the disturbances that alter the habitat quality (Shetti et al. 2015).

The fluctuation of fish numbers and species is greatly influenced by water quality such as physical, chemical and biological factors, topography, hydrological characteristics, habitat, availability of nutrients, and climate change [39], [43]. The water quality of Brantas River has contributed to the fish population. The peak of pollution level in rainy season may hamper the fish population. This is supposed to be the cause of the decrease in abundance in the rainy season. Water quality also differs between locations due to differences in elevation, levels of pollution and dissolution of chemical factors in water. Areas with higher elevations generally have lower temperatures and pollution, while locations near industries that are at low elevations generally have high temperatures and levels of pollution. Therefore monitoring and evaluation of fish diversity needs to be a concern. For this reason, conservation efforts can be carried out with strict aquaculture supervision, harvesting exotic fish from rivers, preserving habitat, controlling pollution, and controlling catching of endemic fish.

\section{CONCLUSION}

This study collected 12 fish species in Brantas River. The abundance and diversity peaked in middle elevation. This shows that there is an effect of elevation on the similarity of the composition of the fish caught. Three species (Oreochromis mosambicus, Clarias batracus, Oreochromis niloticus) were considered as non-native. Compared to previous study this result indicated a trend in fish diversity decline in Brantas River

\section{ACKNOWLEDGMENT}

I would like to thank the ministry of research and higher education who facilitated the DN-LPDP BUDI scholarship program for the funding support can continue their $\mathrm{PhD}$ studies at Brawijaya University Malang. I would also like to thank Majapahit Islamic University (UNIM) for their permission to further study S3 and to the academics of GDP at the Department of Biology, Faculty of Mathematics and Natural Sciences, Brawijaya University and my supervisors for their patience in guiding me.

\section{References}

[1] B. Kang et al., "Fish and fisheries in the Upper Mekong: Current assessment of the fish community, threats and conservation," Rev. Fish Bio. Fish., vol. 19, pp. 465- 
480, 2009, doi: 10.1007/s11160-009-9114-5.

[2] U. K. Sarkar et al., "Freshwater fish biodiversity in the River Ganga (India): changing pattern, threats and conservation perspectives," Rev Fish Biol Fish., vol. 22, pp. 251-272., 2012.

[3] V. Hermoso, M. Clavero, F. Blanco-Garrido, and J. Prenda, "Invasive species and habitat degradation in Iberian streams: an analysis of their role in freshwater fish diversity loss," Ecol Appl, vol. 21, pp. 175-188, 2011.

[4] B. Gallardo, M. Clavero, M. I. Sánchez, and M. Vilà, "Global ecological impacts of invasive species in aquatic ecosystems," Glob Chang Biol, vol. 22, pp. 151-163, 2016.

[5] J. D. M. Knight, "Invasive ornamental fish: a potential threat to aquatic biodiversity in peninsular India," $J$. Threat. Taxa, vol. 2, pp. 700-704, 2010.

[6] J. R. S. Vitule, F. Skora, and V. Abilhoa, "Homogenization of freshwater faunas after the elimination of a natural barrier by a dam in Neotropics," Biodiv Distrib, vol. 18, pp. 111-120, 2012.

[7] A. Ricciardi, M. F. Hoopes, M. P. Marchetti, and J. L. Lockwood, "Progress toward understanding the ecological impacts of non-native species," Ecol Monogr, vol. 83, pp. 263-282, 2013.

[8] J. R. S. Vitule, C. A. Freire, and D. Simberloff, "Introduction of non- native freshwater fish can certainly be bad," Fish Fish, vol. 10, pp. 98-108, 2009, doi: 10.1111/j.1467-2979.2008.00312.x.

[9] D. Simberloff and J. R. S. Vitule, "A call for an end to calls for the end of invasion biology," Oikos, vol. 123, pp. 408-413, 2014.

[10] L. Valéry, H. Fritz, and J. C. Lefeuvre, "Another call for the end of invasion biology," Oikos, vol. 122, pp. 11431146, 2013.

[11] J. Cucherousset and J. D. Olden, "Ecological impacts of non-native freshwater," Fisheries, vol. 36, pp. 215-230, 2011.

[12] D. M. Richardson and A. Ricciardi, "Misleading criticisms of invasion science: A field guide," Divers Distrib, vol. 19, pp. 1461-1467, 2013.

[13] W. S. Lakra, "Biodiversity, ecohydrology, threat status and conservation priority of the freshwater fishes of river Gomti, a tributary of river Ganga (India)," Environmentalist, vol. 30, no. 1, pp. 3-17, 2010.

[14] U. C. Goswai, S. K. Basistha, D. Bora, K. Shyamkumar, B. Saikia, and K. Changsan, "Fish diversity of North East India, inclusive of the Himalayan and Indo Burma biodiversity hotspots zones: A checklist on their taxonomic status, economic importance, geographical distribution, present status and prevailing threats," Int $J$ Biodivers Conserv, vol. 4, no. 15, pp. 592-613, 2012, doi: 10.5897/IJBC11.228.

[15] M. S. Hossain, N. G. Das, S. Sarker, and M. Z. Rahaman, "Fish diversity and habitat relationship with environmental variables at Meghna river estuary, Bangladesh," Egyp J Aquat. Res, vol. 38, pp. 213-226, 2012, doi: 10.1016/j.ejar.2012.12.006.
[16] M. M. Rahman, M. Y. Hossain, F. Ahamed, B. R. F. Subba, E. M. Abdallah, and J. Ohtomi, "Biodiversity in the Padma distributary of the Ganges River, Northwestern Bangladesh: Recommendations for Conservation," World J Zool., vol. 7, no. 4, pp. 328-337, 2012.

[17] A. M. Imteazzaman and S. M. Galib, "Fish fauna of Halti Beel, Bangladesh," Inter J Curr Res., vol. 5, no. 1, pp. 287-290, 2013.

[18] S. M. Galib, S. M. A. Naser, A. B. M. Mohsin, N. Chaki, and M. F. H. Fahad, "Fish diversity of the River Choto Jamuna, Bangladesh: present status and conservation needs," Int J Biodivers Conserv, vol. 5, no. 6, pp. 389395, 2013.

[19] C. T. Leveque, D. Oberdorff, M. L. J. Paugy, P. A. Stiassny, and Tedesco, "Global diversity of fish (Pisces) in freshwater," Hydrobiologia, vol. 595, pp. 545-567, 2008.

[20] Y. Risjani et al., "Biodiversity Inventory Survey of Brantas River," 1998.

[21] Y. Kurniawan, Fakrurrozi, and A. Kurniawan, "Ethnozoology study of Cempedik fish in Lenggang Gantung River, East Belitung Regency," Aquat. J. Aquat. Resour., vol. 10, pp. 32-36, 2016.

[22] Suharijanti et al., "Inventory of freshwater and sea Types in East Java Waters," J Fish, vol. 2, no. 1, pp. 7-12, 2008.

[23] Saanin, Fish identification key. Bandung: Van Hoeve, 1988.

[24] J. Baker, Simply Fish. London: Faver \& Faber, 1988.

[25] M. Kottelat, A. J. Whitten, S. N. Kartikasari, and S. Wirjoatmodjo, Freshwater Fish (Western Indonesia and Sulawesi) Periplus. Jakarta, 1993.

[26] A. Hayati et al., "Water quality and fish diversity in the Brantas River, East Java, Indonesia. 22(2):," J Biol Res, vol. 22, no. 2, pp. 43-49, 2017.

[27] J. Carvajal-Quintero et al., "Variation in freshwater fish assemblages along a regional elevation gradient in the northern Andes, Colombia," Ecol Evol, vol. 5, pp. 1-13, 2015, doi: 10.1002/ece3.1539.

[28] A. Askeyev et al., "River fish assemblages along an elevation gradient in the eastern extremity of Europe," Env. Biol Fish, vol. 100, pp. 585-596, 2017, doi: 10.1007/s10641-017-0588-z.

[29] H. R. Esmaeili, A. Teimory, F. Owfi, K. Abbasi, and B. W. Coad, "Alien and invasive freshwater fish species in Iran: Diversity, environmental impacts and management.," Iran J Ichthyol, vol. 1, pp. 61-72, 2014.

[30] M. P. Carey and D. H. Wahl, "Native fish diversity alters the effects of an invasive species on food webs," Ecology, vol. 91, pp. 2965-2974, 2010, doi: 10.1890/091213.1.

[31] T. A. Zengeya, M. P. Robertson, A. J. Booth, and C. T. Chimimba, "A qualitative ecological risk assessment of the invasive Nile tilapia, Oreochromis niloticus in a sub- tropical African river system (Limpopo River, South Africa)," Aquat. Conserv Mar Freshw Ecosyst, vol. 23, pp. 51-64, 2013, doi: 10.1002/aqc.2258. 
[32] D. E. Gu et al., "The impacts of invasive Nile tilapia (Oreochromis niloticus) on the fisheries in the main rivers of Guangdong Province, China," Biochem Syst Ecol, vol. 59, pp. 1-7, 2015.

[33] J. R. Wilson, R. J. Saunders, and K. S. Hutson, "Parasites of the invasive tilapia Oreochromis mossambicus: evidence for co-introduction," Aquat Invasions, vol. 14, no. 2, pp. 332-349, 2019.

[34] A. Magalhães, B. Magalhães, and C. M. Jacobi, "Colorful invasion in permissive neotropical ecosystems: establishment of ornamental non-native poeciliids of the genera Poecilia/Xiphophorus (Cyprinodontiformes: Poeciliidae) and management alternatives," Neotrop Ichthyol., vol. 15, no. 160094, 2017, doi: 10.1590/19820224-20160094.

[35] V. D. Daga, F. Skóra, A. A. Padial, V. Abilhoa, E. A. Gubiani, and J. R. S. Vitule, "Homogenization dynamics of the fish assemblages in Neotropical reservoirs: comparing the roles of introduced species and their vectors," Hydrobiol, vol. 746, pp. 327-347, 2015, doi: 10.1007/s10750-014-2032-0.

[36] K. Gois, F. Pelicice, L. Gomes, and A. Agostinho, "Invasion of an Amazonian cichlid in the Upper Paraná River: facilitation by dams and decline of a phylogenetically related species," Hydrobiol, vol. 746, 2015, doi: 10.1007/s10750-014-2061-8.

[37] F. M. Pelicice, J. D. Latini, and A. A. Agostinho, "Fish fauna disassembly after the introduction of a voracious predator: main drivers and the role of the invader's demography," Hydrobiol, vol. 746, pp. 271-283, 2015, doi: 10.1007/s10750-014-1911-8.

[38] F. M. Pelicice, J. R. S. Vitule, J. D. P. Lima, M. L. Orsi, and A. A. Agostinho, "A serious new threat to Brazilian freshwater ecosystems: The naturalization of nonnative fish by decree," Conserv Let, vol. 7, pp. 55-60, 2014, doi: $10.1111 /$ conl.12029.

[39] L. B. Li and L. L. Zheng, "Biomonitoring and bioindicators used for river ecosystem: definititions, approaches and trends," ISEIS, vol. 2, pp. 1510-1524, 2010.

[40] S. A. R. Hashemi and H. Ansary, "Biomass and production of fish species in the Shadegan Wetland," Iran. Glob. Vet, vol. 9, pp. 123-128, 2012, doi: 10.5829/idosi.gv.2012.9.2.56370.

[41] M. S. Kornis, S. Sharma, and M. J. V. Zanden, "Invasion success and impact of an invasive fish, round goby, in great lakes tribu-taries.," Divers Distrib, vol. 19, pp. 184-198, 2013.

[42] K. Theoharides and J. Dukes, "Plant invasion across space and time: Factors fffecting nonindigenous species success during four stages of Invasion," New Phytol., vol. 176, pp. 256-73, 2007, doi: 10.1111/j.14698137.2007.02207.x.

[43] S. A. Mohite and J. S. Samant, "Impact of environmental change on fish and fisheries in Warna River Basin, Western Ghats India," Int Res J, vol. 2, no. 6, pp. 61-70, 2013.

[44] Murphy, G.E. and Romanuk, T.N., 2014. A, meta-analysis of declines in local species richness from human disturbances. Ecology and evolution, 4(1), pp.91103.

[45] Norizan Ab Ghani, Fadzli Adam, Berhanundin Abdullah, Jumadil Saputra, Dara Aisyah H.M. Ali Puteh, Factors Influencing the Quality of Life of Malaysian Fishermen, WSEAS Transactions on Environment and Development, ISSN / E-ISSN: 1790-5079 / 2224-3496, Volume 15, 2019, Art. \#27, pp. 238-245.

[46] I. Sumardjoko and M. H. Akhmadi. Pengembangan Infrastruktur Konektifitas Sebagai Daya Ungkit Ekonomi Dan Pemangkas Kemiskinan Jawa Timur. Jurnal Manajemen Keuangan Publik, vol 3, no 1, 2019. 22-31.

[47] Suryaningsih S, Sukmaningrum S, Simanjuntak SBI, Kusbiyanto. 2018. Diversity and longitudinal distribution of freshwater fish in Klawing River, Central Java, Indonesia. Biodiversitas 19 (1): 85-92. DOI: 10.13057/biodiv/d190114.

[48] SUHESTRI SURYANINGSIH $\bullet$, DIAN BHAGAWATI, SRI SUKMANINGRUM, SUGIHARTO, I.G.A. AYU RATNA PUSPITASARI. Freshwater fish diversity in three tributary streams in Serayu Basin, Central Java, Indonesia Biodiversitas Volume 21, Number 12, December 2020, 5811-5817.

[49] Rachmatika, I., Sjafei, D., \& Nurcahyadi, W. (2017). Fish Diversity in Cibareno River, Gunung Halimun National Park: its unique assemblage, management, and conservation consideration (Keanekaragaman Ikan di S. Cibareno, TN. Gunung Halimun: keunikan, manajemen, dan konservasinya). Jurnal Iktiologi Indonesia, 2(2), 4155. https://doi.org/10.32491/jii.v2i2.264

[50] Muchlisin, Zainal \& Siti-Azizah, M.. (2009). Diversity and distribution of freshwater fishes in Aceh waters, Indonesia. International Journal of Zoological Research. 5. 62-79. 10.3923/ijzr.2009.62.79.

[51] Li J., Huang L., Zua L, Kano Y., Sato T., Yhara T. (2012).

Spatial and temporal variation of fish assemblages and their associations to habitat variables in a mountain stream of north Tiaoxi River, China. Environmental Biology of Fishes, 93: 403-417.

[52] Murphy G.E.P., Romanuk T. N. (2014) A meta-analysis of declines in local species richness from human disturbances. Ecology and Evolution, 4(1): 91-103.

[53] Shetty A, Venkateshwarlu M, Muralidharan M (2015) Effect of water quality on the composition of fish communities in three coastal rivers of Karnataka, India. Int J Aquat Biol 3(1):42-51

\section{Creative Commons Attribution License 4.0 (Attribution 4.0 International, CC BY 4.0)}

This article is published under the terms of the Creative Commons Attribution License 4.0 https://creativecommons.org/licenses/by/4.0/deed.en US 
INTERNATIONAL JOURNAL OF BIOLOGY AND BIOMEDICAL ENGINEERING

APPENDIX
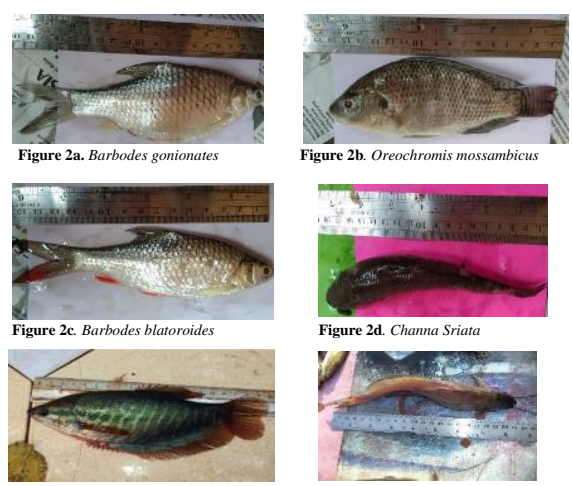

Figure 2e. Trichanogaster tricepterus

Figure 2f. Mysustis planiceps

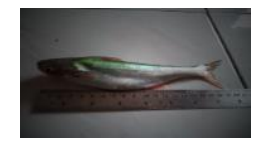

Figure 2g. Pangasius djambal
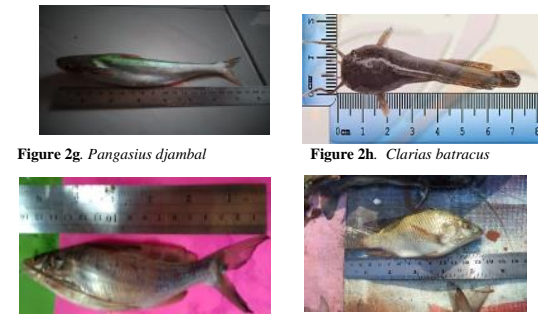

Figure 2i. Pangasius micronumus

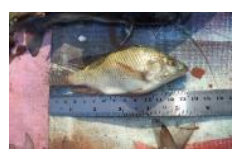

Figure 2j. Poecilla reticulata
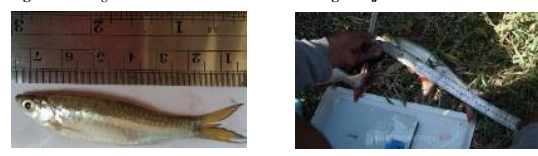

Figure $2 k$. Oreochromis niloticus

Figure 21. Hemibragus nemurus

Fig 2. Recent Fish Species in the Brantas River 